Yavaş, Doğan (2017). "Bursa Şehir Surlarında Ortaya Çıkan Zindanın Restorasyonu”. Uludağ Üniversitesi Fen-Edebiyat Fakültesi Sosyal Bilimler Dergisi, C. 18, S. 32 , s. $55-75$.

DOI: 10.21550/sosbilder.298184

\title{
BURSA ŞEHİR SURLARINDA ORTAYA ÇIKAN ZINDANIN RESTORASYONU
}

\author{
Doğan YAVAŞ*
}

Gönderim Tarihi: Temmuz 2016

Kabul Tarihi: Kasım 2016

\section{ÖZET}

Zindankapı kesiminde yapılan kazı çalışmaları sonucu, Bursa antik şehir sur dokusunun önemli bir parçası olan zindan ortaya çıkartılmıştır. Zindanın restorasyonu amacıla ilk aşamada belgeleme ve rölöve çalışmaları yapılarak, 3 dönem halinde restitüsyon projeleri hazırlanmıştır. Bursa zindanının ayă̆a kaldırlarak müze-sosyal tesis fonksiyonuyla yeniden kullanımının sağlanması amacıyla hazırlanan restorasyon projeleri ise, 2013 yılında Bursa Kültür Varlıklarını Koruma Kurulu tarafindan uygun bulunarak onaylanmıştır. Bu çalı̧̧mada, Bursa şehir surlarının son bölümünde ve hisar gibi iyi korunan bir alanda yer alan zindanın, bir kültür varlığı olarak korunması ve kullanımında süreklilik sağlanarak özgün özellikleriyle geleceğe aktarılması konusunda, Dr. Mimar İbrahim Yılmaz tarafindan üretilen restorasyon projesi anlatılacaktır.

Anahtar Kelimeler: Bursa Zindanı, şehir surları, kültür varlığı, restitüsyon, restorasyon

\section{Restoration of the Dungeon Recovered in Bursa City Walls}

ABSTRACT

As a result of excavations in Zindankap District, the dungeon was revealed which is a significant part of the ancient urban texture. Survey and restitution projects

\footnotetext{
* Yrd. Doç. Dr., Uludağ Üniversitesi Fen- Edebiyat Fakültesi Sanat Tarihi Bölümü, dogany@uludag.edu.tr

Uludağ Üniversitesi Fen-Edebiyat Fakültesi Sosyal Bilimler Dergisi Uludağ University Faculty of Arts and Sciences Journal of Social Sciences Cilt: 18 Sayı: 32 / Volume: 18 Issue: 32
} 
were completed in previous period. Besides the reconstruction of the Bursa Dungeon, the restoration projects that were prepared with the purpose of the re-use of the dungeon as museum- social facilities function were approved by Bursa Cultural and Natural Heritage Preservation Board in 2013. In this paper, the restoration projects that were prepared by Dr. Arch. Ibrahim Yllmaz will be discussed which were made according to the restitution project about the preservation as a cultural assets and transferring of the dungeon to the next generations which is located at the end of the Bursa city walls. Also restoration methods and practices that were proposed by the designer of the project will be explained in this content.

Key Words: Bursa Dungeon, city walls, cultural assets, restitution, restoration

\section{GİRIŞ}

Bursa şehir surlarının mimarisini oluşturan 3 temel unsur içinde yer alan kuleler, kapılar ve beden duvarlarının ortaya çıkartılması ve onarılması çalışmaları 2002 yılında başlayıp günümüzde de halen devam etmektedir. Bu kapsamda Bursa Surlarına ait unsurların, Dr. Mimar İbrahim Yılmaz tarafindan çeşitli zamanlarda yapılan tespit belgeleme, rölöve çizimleri, restitüsyon ve restorasyon projeleri ile restorasyon uygulamaları proje müellifinin sorumluluğu altında yürütülmüsstür. $\mathrm{Bu}$ bağlamda, son zamanlarda yapılan kazılarla ortaya çıkartılan ve oldukça harap durumda olduğu tespit edilen Bursa zindanına ait belgeleme, rölöve, restitüsyon ve restorasyon projeleri de yine Dr. Mimar İbrahim Yılmaz tarafından hazırlanmıştır. Zindana ait restorasyon projeleri Bursa Kültür Varlıklarını Koruma Kurulunun 14.11.2013 tarih ve 2603 sayılı kararı ile uygun bulunarak onaylanmıştır.

Ortaçağ şehir surları içinde yer alan zindanlar, hürriyeti kısıtlayıcı cezaların olduğu gibi bedeni cezalarında uygulandığ 1 dışa kapalı mekânlardır (Yılmaz 2016b). Zindanlar genellikle şehir surlarının dışında veya surun son bölümlerinde hisar gibi iyi korunan alanlarda tasarlanmıştır. Zindanların şehir surlarının dış bölümünde ve çoğu zaman yer altında planlanmasının amacı, bedeni işkencede çıkan seslerin şehir içinden duyulmasının engellenmek istenmesidir (Burger

Uludağ Üniversitesi Fen-Edebiyat Fakültesi Sosyal Bilimler Dergisi Uludağ University Faculty of Arts and Sciences Journal of Social Sciences

Cilt: 18 Sayı: 32 / Volume: 18 Issue: 32 
2009). Zindanlar, suçun türüne ve bulunduğu yere göre saray, tersane ve kale zindanları olarak çeşitlenmektedir (Daşcıoğlu 2006).

$\mathrm{Bu}$ bağlamda, ortaçă̆ şehir surları kapsamında yer alan zindanların, yukarıdaki paragrafta anlatılan genel özelliklerine sahip ve kale zindanı sinıflamasına giren Bursa zindanı, şehir surlarında savunmanın güç olduğu güney kısımda, doğudan batıya doğru ilerleyen çift surun son bulduğu bölümde yer almaktadır. Zindanın kapısı iki sur arasındaki boşluğa açılmaktadır. $\mathrm{Bu}$ kapı kuzey yönünde bulunan dörtgen bir kule ile korunmaktadır (Yılmaz 2014). Zindanın antik şehrin sur planı içerisindeki yeri, Yılmaz (Yılmaz 2014) tarafından yapılan antik şehrin restitüsyon planı üzerinde gösterilmiştir (Çizim 1).

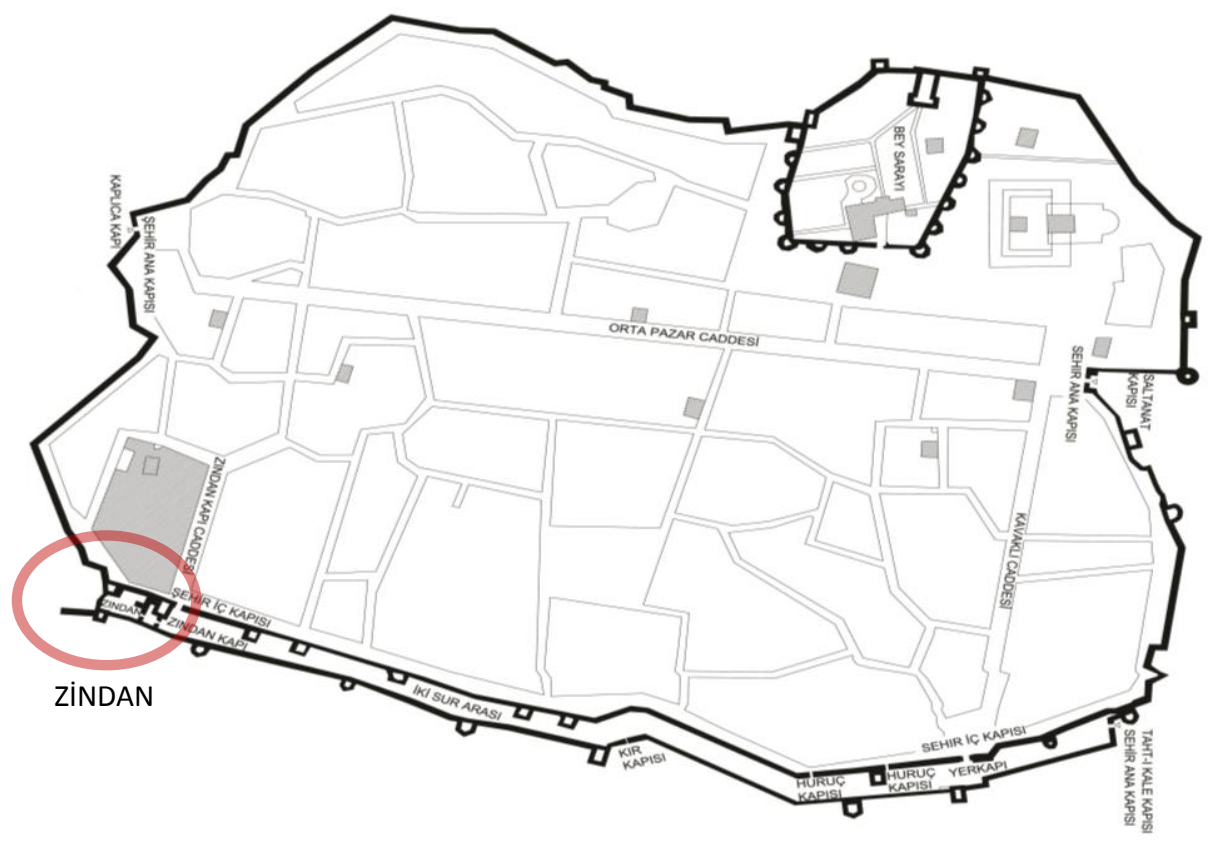

Çizim 1: Bursa antik şehir restitüsyon planında zindanın yeri (Yılmaz, 2014)

Uludağ Üniversitesi Fen-Edebiyat Fakültesi Sosyal Bilimler Dergisi Uludağ University Faculty of Arts and Sciences Journal of Social Sciences Cilt: 18 Sayı: 32 / Volume: 18 Issue: 32 
Bu plana göre zindana, ilki iki sur arasına açılan iki aşamalı kapı düzeniyle girilmektedir. İki kapı arasında genişçe bir şaşırtma avlusu bulunmaktadır. Yine bu plana göre, zindanın üç büyük kule ve bu kulelere bağlanan yüksek beden duvarlarıyla birlikte adeta bir iç kale gibi korunduğu tespit edilmiştir. Bursa mimarlık tarihinin ve antik şehir dokusunun önemli bir parçası olarak belgelenen zindanın ihya edilmesi, müze-sosyal tesis fonksiyonuyla işlevlendirilmesi, dolayısıyla yeniden kullanımın sağlanarak geleceğe aktarılması konusunda hazırlanan restorasyon projesinin bu makale içeriğinde anlatılması çalışmanın amacını oluşturmaktadır. Ayrıca, proje müellifi tarafından zindanın restorasyonuna yönelik belirlenen yöntem ve uygulama önerileri de bu kapsamda ele alınacaktır.

\section{BURSA ZINDANI RESTORASYONU KAPSAMI ve UYGULAMA ÖNERILERİ}

Tarihi yapılar korunması gerekli kültür varlıklarıdır. Bu yapılar, yapıldıkları dönemde ne kadar mükemmel kalitede inşa edilmiş olurlarsa olsunlar, zaman içerisinde çeşitli nedenlere bağlı olarak farklı düzeylerde hasar görmüştür (Yılmaz 2016a). Yaşayan bir belge niteliğinde olan bu yapılar kendi dönemlerinin sosyo-kültürel ve ekonomik özelliklerini, malzeme özellikleri ve yapım tekniklerini günümüze kadar taşımışlardır (Çelik ve Yazgan 2007). Günümüzde bu eserlerde, yapılacak müdahalenin türüne ve derecesine bağlı olarak korumaya ve yapının ömrünü uzatmaya yönelik olarak gerçekleştirilen tüm müdahaleler restorasyon eylemi olarak adlandırılmaktadır (Yılmaz 2016a). Restorasyon çalışmalarında, anıtsal yapıların bir tarih ve kültür belgesi olarak korunup geleceğe özgün özellikleri ile aktarılmas1 amacıyla mimari ve yapımsal olmak üzere iki müdahale hali söz konusudur (Kuban 2000). Restorasyonun mimari boyutunun en önemli aşaması restorasyon projesidir. Anıtsal niteliği olan birçok tarihsel yapı, özgün işlevini yitirmekte ya da işlevsel olarak eskimektedir. Yapının fiziksel ömrü, işlevsel ömründen fazla olduğundan ya işlev değişikliği ya da günümüz standartlarına uyum sağlama ihtiyacı ortaya çıkmaktadır

Uludağ Üniversitesi Fen-Edebiyat Fakültesi Sosyal Bilimler Dergisi Uludağ University Faculty of Arts and Sciences Journal of Social Sciences Cilt: 18 Sayı: 32 / Volume: 18 Issue: 32 
(Altınoluk 1998). Günümüz konfor standartlarına uyum sağlayamayan yap1 ise terk edilerek zamanla yok olma sürecine girmektedir. Bu nedenle restorasyon projeleri, sürdürülebilirlik ilkesi doğrultusunda sadece fiziksel koruma değil, sosyo-kültürel yapıyı da içine alan "bütünleşik koruma" düşüncesi ön plana çıkartılarak hazırlanmalıdır. Dolayısıyla tarihi ve kültürel varlıkları yeterince değerlendirmenin, gelecek nesillere aktarmanın en etkin yolu, onların yeniden işlevlendirilerek yaşayan bir varlık haline getirilmesidir (Altınoluk 1998). Bu yüzden korumada müze gibi dondurarak korumanın dışında, koruma kullanma dengesini kurarak, yeni işlevler vererek korumaya önem verilmelidir (Çelik ve Yazgan 2007). Bu bağlamda, proje müellifi tarafından hazırlanan restorasyon projesinde, zindanın ve zindana ait sur duvarları ile kulelerin onarılması ve ihya edilerek ayağa kaldırılması gibi fiziki korumanın yanında, zindan müze-sosyal tesis fonksiyonuyla işlevlendirilerek, yeniden kullanım ile sürekliliğin sağlandığı düzenlemeler getirilmiştir.

Zindan restorasyon projesinin kapsamı, zindan planını oluşturan; zindan iç boşluğu, zindanı adeta iç kale gibi koruyan üç adet büyük kule, kulelerin içindeki kazamat katları, yer altı zindan odaları, peçenekli duvar ve bu duvarın içinde bulunan zindan odaları ile kuleleri birbirine bağlayan iç ve dış sur beden duvarlarından oluşmaktadır. Ayrıca, proje müellifi tarafindan, restorasyon projesi kapsamında uygulamaya yönelik öneriler de geliştirilmiştir. Buna göre, restorasyon uygulamasında ilke olarak genellikle her bölümün kendi görünen malzemesinin türü ve tekniğinde onarılması yöntemi, tamamlamalarda ise farklı örgü tekniklerinin kullanılmasının benimsenmesi gerektiği belirtilmiştir. Bu bağlamda, proje müellifi Dr. Mimar İbrahim Yılmaz tarafindan hazırlanan restorasyon raporunda uygulamada uyulmas1 gerekli restorasyon önerileri aşağıda açıklanmıştır.

- Uygulama çalışmalarında, zindan iç boşluğunda bulunan ve Bursa Büyükşehir Belediyesi tarafından kamulaştırılarak yıkılmış, günümüze ait aykırı binaların temel, moloz ve diğer kalıntıları öncelikli

Uludağ Üniversitesi Fen-Edebiyat Fakültesi Sosyal Bilimler Dergisi Uludağ University Faculty of Arts and Sciences Journal of Social Sciences Cilt: 18 Sayı: 32 / Volume: 18 Issue: 32 
olarak temizlenecektir. Ancak, temizlik ve kazı sırasında zindan iç boşluğunda ortaya çıkabilecek özgün seğirdim yoluna ait döşeme taşları ile mevcut kalıntıların yerinde korunmasına azami derecede özen gösterilecektir.

- İç ve dış sur duvarları ile kuleler üzerinde, yıkılan binalardan kalan sıva ve tuğla tabakaları, betonarme parçaları ile diğer aykırı eklentiler özgün yapıdan arındırılacaktır. Arındırma işlemi, sur duvarlarına zarar vermeden itina gösterilerek gerçekleştirilecektir.

- Yapılacak restorasyon çalışmasında, zindanı ve sur mimarisini oluşturan, günümüze ulaşmış hiçbir mimari eleman kalıntısı yok edilmeyecektir. Mevcut kalıntıların yıkılıp yerine yenisinin yapılması gibi bir uygulamaya kesinlikle izin verilmeyecektir. Mevcut kalıntılar korunarak bu kalıntılar üzerinde onarım, sağlamlaştırma ve tamamlamaya yönelik çalışmalar yapılacaktır. Ayrıca, özgün sur planının günümüzde yok olan ancak, özgün plana dönüşü sağlayacak mimari elemanlarda yeterli ölçülerde yeniden yapım yöntemi kullanılacaktır.

- İlke olarak gerek mimari malzemenin yerine kullanılacak yeni malzemelerde, gerekse yapım tekniğinde yapay malzeme kullanılmayacak ve çok gerekmedikçe çağdaş tekniklere yer verilmeyecektir.

-Yüksekliğini kaybetmiş bölümlerde duvarlar hem sur duvarı kimliğini ifade edecek şekilde ve ölçüde yükseltilecek, hem de korunması sağlanacak şekilde, yukarıda da anlatıldığı gibi, olabilecek mimari tecavüzlerden arındırılacaktır.

- Her bölge, o alandaki halen görülen özgün özelliklerine göre onarılacak, ilkselleştirilmeye gidilmeyecektir. Çünkü bugün üzerinde gördügümüz ve çağdaş olmayan her müdahale surların tarihinin bir parçasıdır.

Uludağ Üniversitesi Fen-Edebiyat Fakültesi Sosyal Bilimler Dergisi Uludağ University Faculty of Arts and Sciences Journal of Social Sciences

Cilt: 18 Sayı: 32 / Volume: 18 Issue: 32 
- Spolien (devşirme) malzemeler genellikle mermerdir. Şehrin yapı tarihinin önemli bir parçasını ifade eden devşirme malzemeler korunacaktır. Duvar tamamlamalarında renk uyumu sağlaması açısından kalker kullanılması önerilmiştir. Moloz taşlı bölümler ise, genelde toplama taşlardan yapıldığı için aynı örgüyü, grinin tonlarında olmak üzere taş ocaklarının molozları kullanılarak sağlamak yerinde olacaktır.

- Plastik onarımlarda, sağlamlaştırma ve tamamlamalarda, ayrıca tüm derzlerde kullanılacak harç, içine tuğla kırığı katılmış kum-kireç karışımı olan horasan harcıdır. Böylece çimento harcına göre hem çok daha uzun ömürlü bir harç kullanılmış olacak, hem de renk uyumu sağlanmış olacaktır. Duvarlarda bulunan tuğla hatıllar ile kemer, tonoz ve kubbe onarımlarında, özgününde olduğu gibi $4 \times 30 \times 30 \mathrm{~cm}$. ebatlarında pişmiş toprak tuğla malzeme kullanılacaktır. Tuğlalar arasındaki derz aralığı tuğla kalınlığında, derz derinliği ise $1 \mathrm{~cm}$. ile 1,5 $\mathrm{cm}$. arasında olacaktır.

- Tüm seyirdim yüzeyleri, içine kum-kireç ve ince tuğla kırıkları katılmış horasan harçlı şap ile ya da 30x30 cm. ebatlarında kırmızı renkli taban tuğlası ile kaplanacaktır.

- Duvar harçlarında bağlayıcı olarak hem akışkanlığı ve boşlukların doldurulmasını sağlayacak, hem de duvar içinde bitki üremesini önleyecek kimyasal malzeme kullanılması önerilmektedir. Böylelikle harcın tüm boşlukları doldurularak kompakt bir kütle oluşturması sağlanacak, ayrıca duvarın içinde bitki üremesi de önlenmiş olacaktır.

\section{ZINDAN RESTORASYONU}

Proje müellifi tarafindan üretilen, hem fiziki korumanın, hem de yeniden kullanımın sağlandığı bütünleşik korumayı içeren restorasyon projesinin aşamaları aşağıda açıklanmıştır.

\section{A. Restorasyon Projesi}

Uludağ Üniversitesi Fen-Edebiyat Fakültesi Sosyal Bilimler Dergisi Uludağ University Faculty of Arts and Sciences Journal of Social Sciences

Cilt: 18 Sayı: 32 / Volume: 18 Issue: 32 


\section{Zindan İç Boşluğu}

Zindan iç boşluğu 18,50 m. ile 33,65 m. ölçülerindedir. Buraya iki sur arası boşluktan iki ayrı kapı ile girilmektedir. Özgün planda iki kapı arasında bir şaşırtma avlusu bulunmaktadır (Yılmaz 2016/b). Giriş kapılarından, ilki 9 nolu iç kuleden çıkarak dış sur duvarına saplanmaktadır. İkinci giriş kapısı ise yine, aynı şekilde 9 nolu iç kuleden çıkarak, dış sur duvarına bağlanmaktadır. Hazırlanan restorasyon projesinde, daha fazla zindan iç boşluğu bırakılması düşüncesiyle, iki kapının birden değil, iki sur arasından zindana giren ilk kapının yeniden yapılması önerilmiştir (Çizim 2).

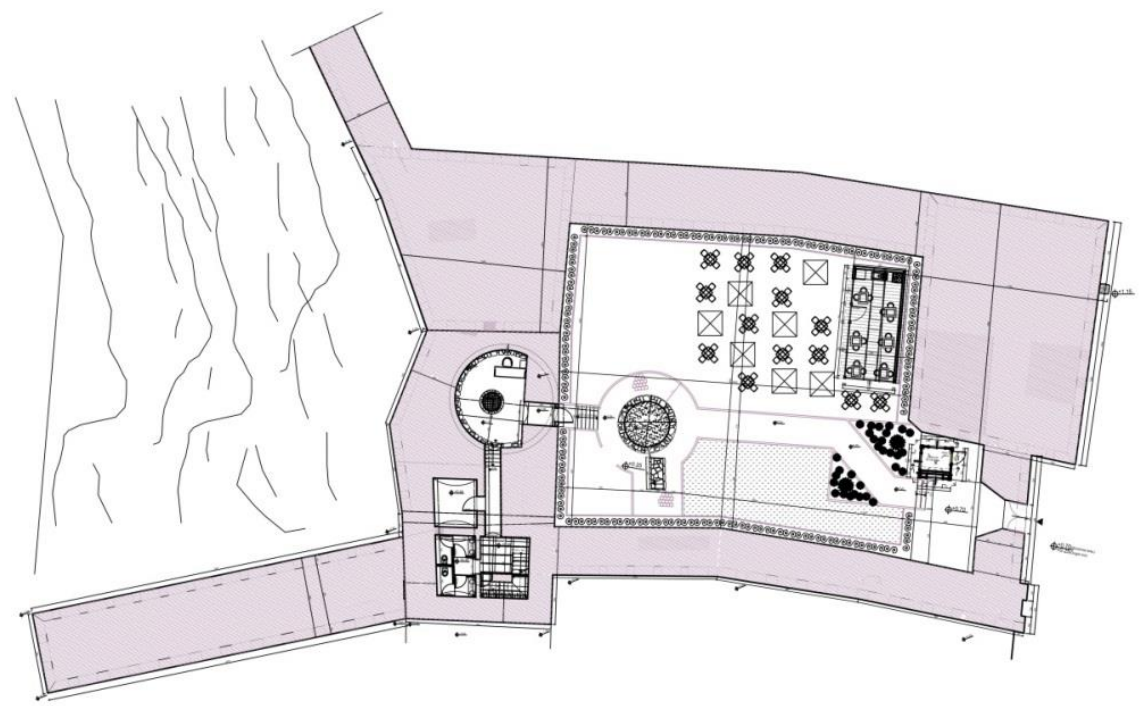

Çizim 2: Zindan planı ve zindana ilk giren kapının plan içindeki yeri

(İ. Yılmaz restorasyon projesinden alınmıştır.)

Zindana giren ilk kapının, restorasyon planında belirtildiği gibi V planına sahip olduğu görülmektedir. Kapının iki sur arasına bakan dar kısmının genişliği, $1.80 \mathrm{~m}$. içte kalan kısmının genişliği ise, $3.50 \mathrm{~m}$. dir. Bu kapı semte de adını veren zindanın esas kapısıdır. Kap1

Uludağ Üniversitesi Fen-Edebiyat Fakültesi Sosyal Bilimler Dergisi Uludağ University Faculty of Arts and Sciences Journal of Social Sciences

Cilt: 18 Sayı: 32 / Volume: 18 Issue: 32 
duvarının saplandığı kuleden, dış sur duvarına kadar toplam uzunluğu, $7.90 \mathrm{~m}$. seğirdime kadar yüksekliği ise $9.70 \mathrm{~m}$. dir. Kapıda gözetleme amaçlı bir de göz odası bulunmaktadır. 9 nolu iç kulenin kazamatı, kapının üst seğirdim kotuna açılmaktadır. Kapının üst seğirdim kotu, aynı zamanda dış sur duvarının seğirdim kotu ile birleşmektedir. Restorasyon projesinde de belirtildiği gibi, kapının yeniden yapım yöntemiyle gerçekleştirilecek restorasyon uygulamasında, duvar iç dolgusu horasan harçlı moloz taşlar; iç ve dış kabuk yüzeyleri ise yuvarlak ve dörtgene yakın biçimde iri boyutlu moloz taşlar kullanılarak örülecektir. Duvar yüzeyindeki derzlerde ise horasan harç kullanılacaktır.

Yine restorasyon projesi kapsamında hazırlanan müdahale paftalarında, zindan iç boşluğunda bulunan moloz taş örgülü kuyu ile pişmiş toprak malzeme kullanılarak yapılmış yatak, üzerindeki eklerden arındırılacak, derzleri temizlenecek, çürütme ve sağlamlaştırma işlemlerinin ardından, horasan harç ile yeniden derz yapılarak bu elemanların korunması sağlanacaktır. Aynı zamanda, zindan iç avlusunda kuyu ve yatak dişında bulunan özgün tuğla ve döşeme parçası gibi kalıntılara herhangi bir müdahale yapılmayıp harabe halinde korunacaktır. Zindan iç boşluğu, projesinde belirtilen özgün kotuna $(+0.25)$ kadar indirilecektir. Bu kotu belirleyen yukarıda da ifade edildiği gibi, mevcut döşeme kalıntıları ve tuğla parçaları bulunmaktadır. Zindan boşluğunda, esas kapıdan girilerek yer altı zindanına doğru giden aks üzerinde bir yürüyüş yolu planlanmıştır. Zindan avlusunda bu yol dışında kalan boşluklar ise, peyzaj ve açık alan düzenlemesi yapılabilecek hacimler olarak ayrılmıştır.

Zindan iç boşluğunda bulunan ana mekânın esas zindan olduğu projede belirtilmektedir. Zindan iç avlusundan geometrik formu yarım daire olan esas zindana 6 basamaklı bir merdiven ile inilmektedir. Aradaki kot farkı $1.10 \mathrm{~m}$. dir. Projede dairesel mekânın eksik olan duvarının önce sağlamlaştırılması, daha sonra da yine projesinde belirtilen özgün üst kotuna kadar moloz taş kullanılarak tamamlanması

Uludağ Üniversitesi Fen-Edebiyat Fakültesi Sosyal Bilimler Dergisi Uludağ University Faculty of Arts and Sciences Journal of Social Sciences Cilt: 18 Sayı: 32 / Volume: 18 Issue: 32 
önerilmiştir. Tamamlanacak dairesel mekânın üzerinin ise, pişmiş toprak tuğla kubbe ile örtülmesi belirtilmiştir. Kubbenin kalınlığ 40 $\mathrm{cm}$. dir. Tuğla kubbe kasnağının üzeri, horasan harcı ile düzeltildikten sonra klasik kiremit ile kaplanacaktır. Tuğla kubbenin iç yüzeyi ise, horasan harç ile sıvandıktan sonra üzeri kireç badana ile boyanacaktır. Ayrıca bu eğrisel mekânın içinde bulunan kuyunun ölçüleri ve derinliği restorasyon projesinde belirtilmiştir. Bu mekânın iç ve dış duvar taş yüzeylerine horasan harçla derz yapılacaktır. Eğrisel mekânı "8 nolu" dış kule ile bağlantısını sağlayan koridorun üzerinde bulunan tuğla tonoz, gerekli çürütme çalışmaları yapıldıktan sonra özgün malzeme ve teknikler kullanılarak tamamlama yapılacaktır. Burada, mevcudu yıkarak yerine yeniden yapım uygulamasına kesinlikle gidilmeyeceği belirtilmiştir. Ayrıca bu koridor güzergahında bulunan zindan odalarının da projesinde belirtilen ölçülerde zindan hücreleri olarak açılması sağlanacaktır. Zindan hücrelerinin önünde, boydan boya yapılacak demir parmaklıklı kapılar ve korkuluklar bulunacaktır. Korkuluk renklerinin ise siyah olacağı müdahale paftalarında belirtilmiştir.

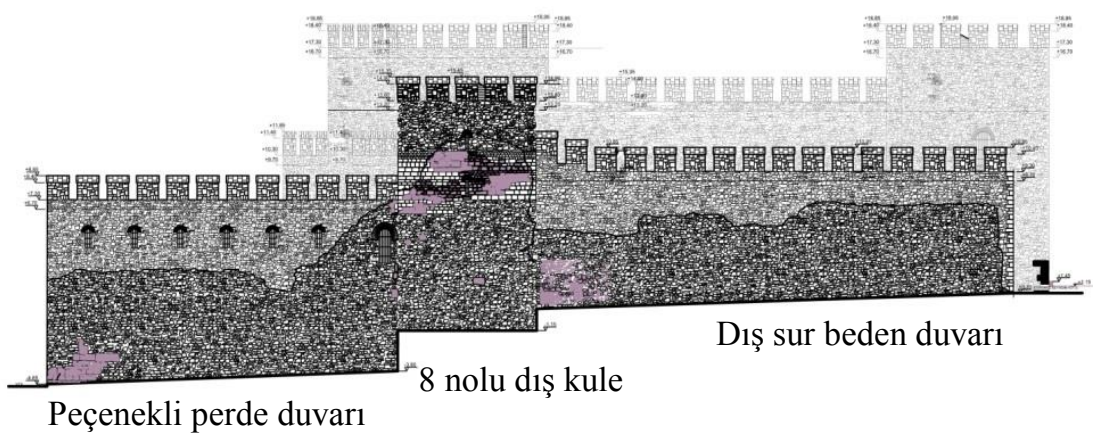

Çizim 3: 8 nolu dış kule özgün kabuk taşları ile bu kuleye saplanan duvarların görünüşü

(İ. Yılmaz, restorasyon projesi ekinden alınmıştır.)

Uludağ Üniversitesi Fen-Edebiyat Fakültesi Sosyal Bilimler Dergisi Uludağ University Faculty of Arts and Sciences Journal of Social Sciences

Cilt: 18 Sayı: 32 / Volume: 18 Issue: 32 


\section{Nolu Dış Kule}

Esas zindandan gelen koridor, 8 nolu dış kulenin ilk kazamatına $(+0.30$ kotu) açılmaktadır. Bu kazamat, kulenin toprak içinde kalan zindan hücresidir. Bu yüzden, bu zindanlara yer altı kule zindanları da denilmektedir. Bizans dönemine tarihlenen bu kulenin özgün dörtgen biçimi Osmanlı döneminde de değişmemiştir. Ebatları, 6.65 x $9.00 \mathrm{~m}$. dir. Kulenin yer altındaki ilk kazamatından sonra +3.70 kotunda ikinci bir kazamatı, +6.70 ve +9.70 kotlarında 3 . ve 4 . kazamatları bulunmaktadır. +3.70 kotundan peçenekli perde duvarında bulunan zindan koridoruna ve zindan odalarına girilmektedir. Kulenin ilk iki kazamatı zindan hücreleri olarak kullanılmakla beraber, diğer kazamatı batı ve kuzey yönündeki dış sur duvarı seğirdimlerine $(+9.70 \mathrm{~m}$. kotu) açılmaktadır. Restorasyon projesinde bu kulenin $13.20 \mathrm{~m}$. kotuna kadar tamamlanması önerilmiştir. Sözü edilen kulenin, özgün dış kabuk taşlarının bir kısmı kule yüzeyinde mevcuttur. Tamamlamalarda kulenin dış özgün kabuk taşlarının yerinde korunacağı belirtilmiştir (Çizim 3).

Ancak, sağlamlaştırma gerekliliğiyle özgün taşların sökülmesi gibi bir durum ortaya çıkarsa, her bir özgün taş numaralandırılıp yer düzlemine aktarılacaktır. İç moloz dolgusunda yapılacak sağlamlaştırmanın ardından, yer düzlemine numaralandırılarak aktarılan özgün kabuk taşları, duvar düzlemindeki yerlerine geri konulacaktır. $\mathrm{Bu}$ kulede yapılacak tamamlamalarda, restorasyon yapıldığını ifade eden farklı doku kullanılması önerilmiştir.

8 nolu dış kule duvar tamamlamalarında, gri renkli iri moloz taş malzemeler, taşların derzlerinde ise horasan harç kullanılacağ restorasyon raporunda belirtilmiştir. Bu kuleye, Fetih Kapısı yönünden gelerek saplanan dış sur beden duvarının dış ve iç yüzey kabuk taşları da horasan derzli ve iri moloz taşlar kullanılarak $+9.70 \mathrm{~m}$. ye kadar tamamlanması projede belirtilmiştir. 


\section{Peçenekli Perde Duvarı}

$\mathrm{Bu}$ duvar, önündeki ovayı daha geniş açıdan gözetlemek ve zindanı korumak amacıyla, 8 nolu diş kuleye bağlı olarak yapılmış geniş seğirdim alanına sahip bir perde duvar yapısıdır. Restorasyon projesinde, bu geniş duvarın içinde zindan koridoru ve bu koridora açılan zindancı holü ile 6 adet zindan odası bulunmaktadır (Çizim 4). Perde duvarına "8 nolu dış kule"nin +3.15 kotundan düz bir koridorla girildiği gibi, kulenin +6.70 kotunda bulunan kazamatından da hem zindan koridoruna, hem de duvar seğirdimine inilmektedir (Çizim 5).

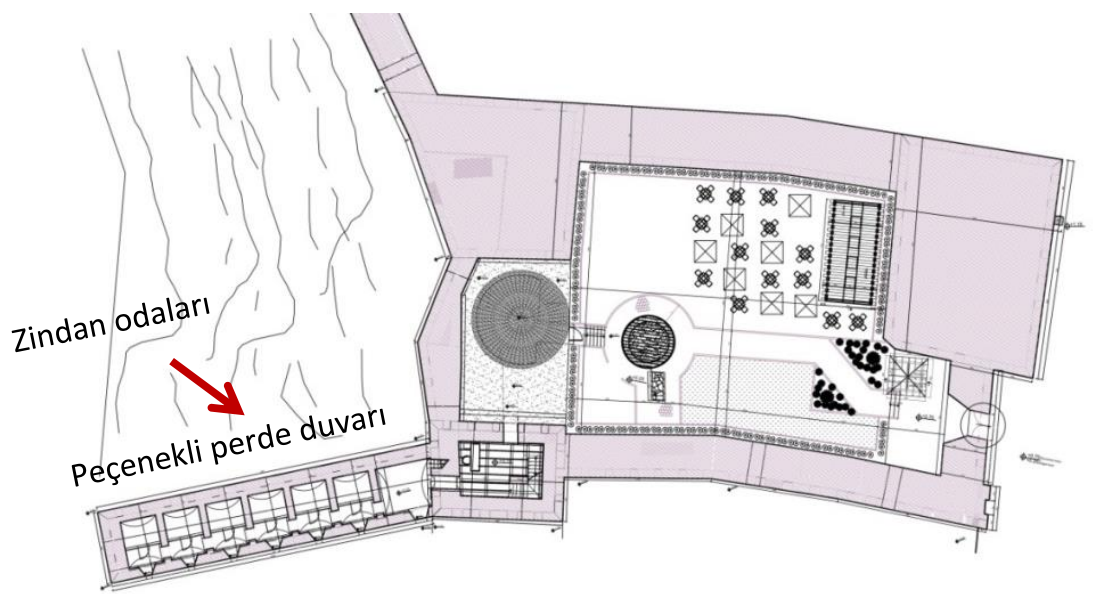

Çizim 4: İçinde zindan odalarının bulunduğu peçenekli perde duvar planı (İ. Yılmaz) (İ. Yılmaz restorasyon projesinden alınmıştır.)

Uludağ Üniversitesi Fen-Edebiyat Fakültesi Sosyal Bilimler Dergisi Uludağ University Faculty of Arts and Sciences Journal of Social Sciences Cilt: 18 Sayı: 32 / Volume: 18 Issue: 32 


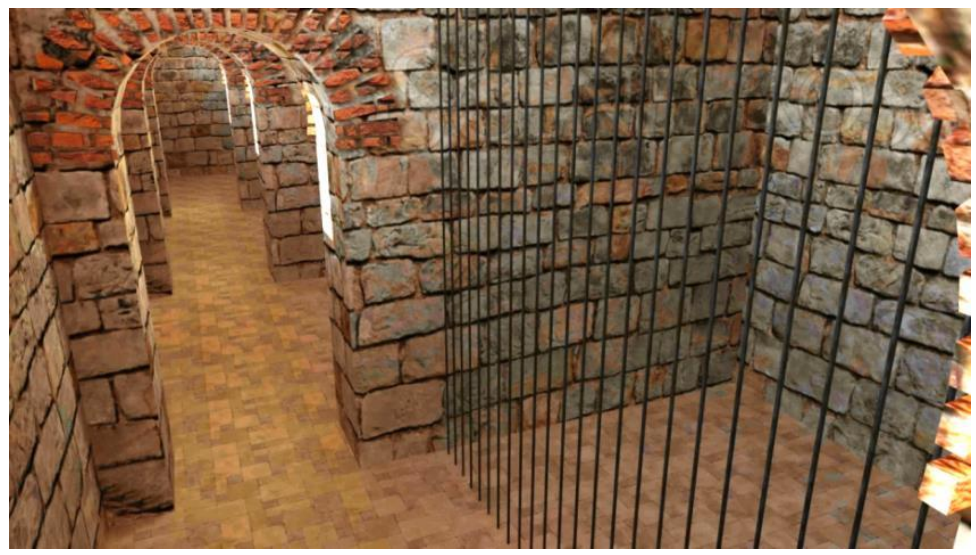

Çizim 5: Peçenekli perde duvarı içinde bulunan zindan odaları ve koridorun render görünüşü

(İ. Yılmaz restorasyon projesi ekinden alınmıştır.)

Rölövesinde perde duvarının zindan hücre bölümlerine ait kalıntıları görülmektedir. Özgün planına ulaşmak amacıyla bu duvarın restorasyon projesinde belirtilen özgün kotuna kadar tamamlanması ve özgün zindan planına kavuşmasının amaçlandığı anlaşılmaktadır. $\mathrm{Bu}$ amaçla, duvarın iç dolgusunun horasan harçlı moloz taşlar kullanılarak tamamlanması önerilmiştir. Duvarın dış ve iç yüzeylerinde ise, düzgün moloz taş yüzey örgüleri yapılması öngörülmüştür. Dış ve iç yüzey moloz taş uygulamalarında horasan derzler kullanılacaktır. Kullanılacak derzler, yüzeyden $1 \mathrm{~cm}$. ile $1,5 \mathrm{~cm}$. arasında içeriden başlatılarak, Orta Bizans dönemi derz sisteminin oluşturulması önerilmiştir.

\section{Nolu Diş Kule}

Batı yönünden kuzeye doğru kırılan dış sur duvarının ikinci dış kulesi olan "9 nolu” dış kulenin ebatları 8.25 x 10.90 m. dir. Bu kuleye, "8 nolu" dış kuleden gelerek saplanan +9.70 kotunda ki dış sur duvarı seğirdim yüzeyi ile "10 nolu" iç kuleden daha yüksek kotta gelen, +13.20 kotundaki iç sur duvarı seğirdimi bulunmaktadır. Bu kulenin, 
belirtilen kotlarda iç ve dış sur beden duvarı seğirdimine açılan 2 adet kazamatı bulunmaktadır. Hazırlanan restorasyon projesinde bu kulenin, $16.70 \mathrm{~m}$. olan iç yüz yüksekliğine kadar, içindeki kazamatlarıyla birlikte tamamlanması önerilmiştir. Tamamlamalarda diğer kulelerde olduğu gibi, duvar iç dolgularında horasan harçlı moloz taş, duvar dış yüzeylerinde ise, horasan harç derzli iri moloz taşlar kullanılması önerilmiştir. Zindan boşluğunun batı kısmında bulunan 8 nolu dış kule ile 9 nolu dış kuleyi birbirine bağlayan ovaya bakan diş sur duvarı, mevcut düzlükten yaklaşık $6.50 \mathrm{~m}$. yüksekliğinde kayalar üzerine oturtulmuştur. $\mathrm{Bu}$ duvarın, kule kazamatlarına giren seğirdim yüzeyine kadar tamamlanması önerilmiştir (Çizim 6).
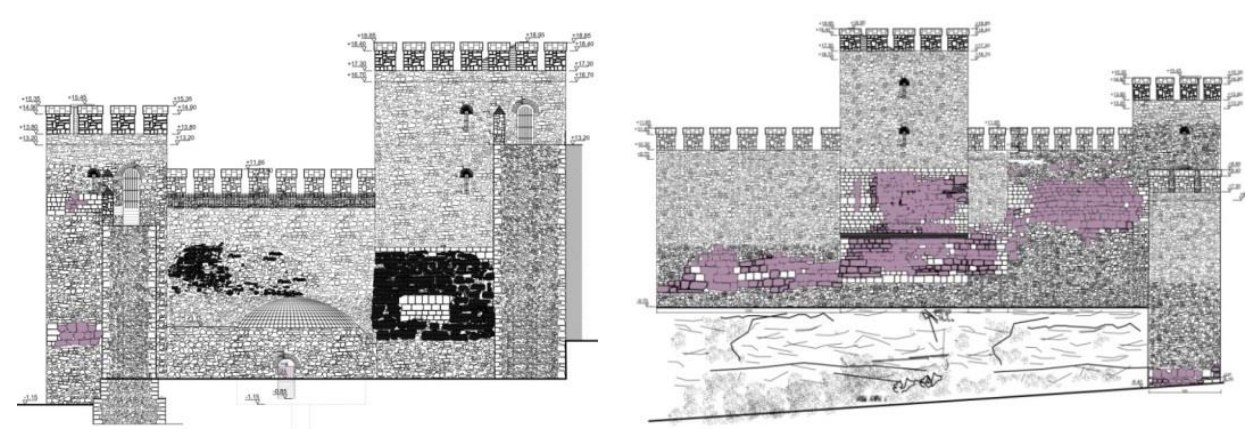

8 nolu diş kule ile 9 nolu diş kuleyi birbirine bağlayan batı duvarının içten görünüşü
8 nolu dış kule ile 9 nolu dış kuleyi bağlayan batı duvarının dıştan

Çizim 6: 8 nolu dış kule ile 9 nolu dış kuleyi birbirine bağlayan batı duvarının tamamlanmış halinin içten ve diştan görünüşü (İ Yılmaz restorasyon projesinden alınmıştır.)

Tamamlanması restorasyon projesinde belirtilen diş sur duvarının seğirdim kotu $9.70 \mathrm{~m}$. dir. Bu duvarın restorasyon çalışması esnasında, duvar yüzeyinde bulunan özgün kabuk taşları ile spolien 
özellikli örgü taşları korunacaktır. Bu taşların erozyona uğramış yüzeyleri ise, gerekli görüldüğü durumlarda temizlenecektir

\section{Nolu İç Kule}

$\mathrm{Bu}$ kule iki sur arasını ve özellikle zindan boşluğunu kontrol eden önemli bir kuledir. Bu kuleye, iki sur arasından zindana ve iç şehre giren kapıların bulunduğu duvarlar saplandığından, aynı zamanda zindana ve iç şehre giriş ve çıkışları da kontrol eden ve koruyan konumdadır. Dış sur duvarının seğirdim kotu $(+9.70)$ ile iç sur duvarının yüksek seğirdim kotu $(+13.20)$ esas alındığında, bu kulenin "9 nolu" dış kule gibi iki kazamatlı olduğu görülmektedir. Kulenin birinci kazamatı, +9.70 kotuyla iki sur arasından giren giriş kapısı seğirdimine açılmaktadır. Kulenin özgün ebatları, $11.00 \times 15.24 \mathrm{~m}$. yüksekliği ise $16.70 \mathrm{~m}$. dir. Yapılacak restorasyon çalışmasında, bu kulenin özgün iki katlı kazamatı ile birlikte tamamlanması önerilmiştir (Çizim 7).

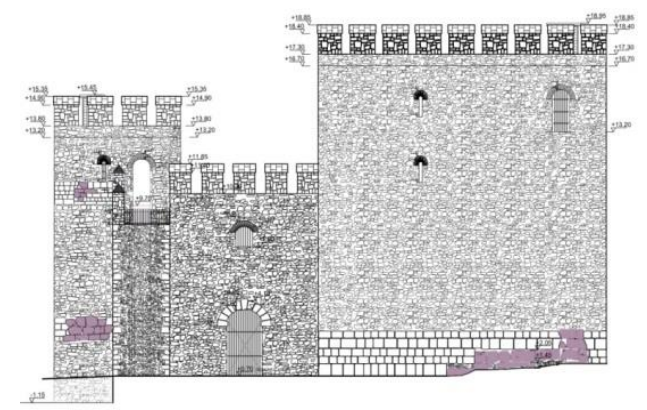

Zindan iç avlusundan 9 nolu iç kule ve zindan girişinin dış cephe görünüşü

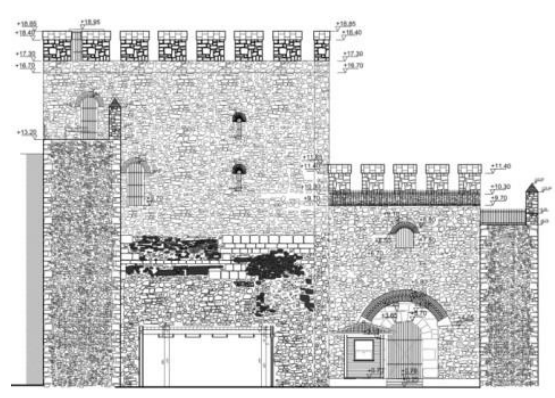

Zindan iç avlusundan 9 nolu iç kule ve zindan girişinin iç cephe görünüşü

Çizim 7: 9 nolu iç kule ile zindan girişinin iç ve dış restorasyon cephe görünüşleri (İ. Yılmaz restorasyon projesinden alınmıştır.) 
Tamamlamada kulenin mevcut tüm kalıntıları sağlamlaştırılacaktır. Tamamlamada iç moloz dolgusunda horasan harç, dış kabukta ise "8 nolu" dış kulede yapılacağı gibi iri moloz taşlarının kullanılması gerektiği restorasyon projesinde belirtilmiştir. Bu kulenin gerek mazgallarında, gerekse kazamat üstü tonozlarında pişmiş toprak yaprak malzeme tuğlalar kullanılarak, horasan harç ile yüzeyden 1 ya da $1,5 \mathrm{~cm}$. içeriden başlamak kaydıyla derz çalışması yapılacaktır.

$\mathrm{Bu}$ bağlamda, zindanın özgün planını oluşturan tüm mimari elemanların tamamlamalarında ve diğer uygulamalarda, restorasyon projesinde ve raporunda belirtilen özelliklere uygun olarak, özgün teknik ve malzemeler kullanılmak suretiyle yapımın gerçekleştirilmesine özen gösterilecektir. Ayrıca kule tamamlamalarında, mevcut özgün kabuk taşı bulunan kısımlarda kısmi düzgün kesim taş tamamlaması, diğer kısımlarda ise bu örgüden farklı bir doku olarak iri moloz taş dokusu kullanılması, restorasyon projesi müdahale paftalarında belirtilmiştir.

\section{B. Yeniden Kullanım Projesi}

Bütünleşik koruma düşüncesiyle üretilen restorasyon projesinin ikinci aşamasını yeniden kullanım projesi oluşturmaktadır. Kullanım projesi ile zindana yeni bir işlev kazandırılarak korunması ve sürekli kullanımın sağlanması amaçlanmıştır. Ancak, yeniden işlevlendirmenin yapılabilmesi için organizasyon şeması ve ihtiyaç programıla yeni işlevin gereksinimleri belirlenmelidir. Çeşitli mekân dönüşümleriyle bu gereksinimler karşılanmaya çalışılmalıdır. Yeniden işlevlendirme sürecinde mekân dönüşümleri yeterli olmuyorsa ya da bir takım eksiklikler ortaya çıkıorsa imkanlar dahilinde ek tasarımına gidilmelidir (Eraybat, 2011). Tarihi yapıda ek tasarımı, yeni bina tasarımına oranla daha sınırlayıcı ve zordur. Çünkü ek yapı tasarımı; tarihi yapının döneminin araştırılması, yapının tanımlanması, geçmişten günümüze geçirdiği müdahalelerin tespit edilmesi, koruma prensiplerinin belirlenmesi, kullanılacak restorasyon tekniklerinin belirlenmesi, tarihi yapıdan gelen verilerin tespit edilmesi, yeni ekin tarihi yapıyla ve

Uludağ Üniversitesi Fen-Edebiyat Fakültesi Sosyal Bilimler Dergisi Uludağ University Faculty of Arts and Sciences Journal of Social Sciences Cilt: 18 Sayı: 32 / Volume: 18 Issue: 32 
çevresiyle uyumu açısından bakıldığında sanat ve mimarlık tarihi, kent tarihi, restorasyon ve koruma bilimi, tasarım gibi çeşitli bilgi birikimlerini gerektiren bir uzmanlık alanıdır (Eyüpgiller vd, 2008). Ayrıca, hazırlanan yeniden kullanım projesinde, yapının özgün özelliklerinin de bozulmamasına özen gösterilmesi gerekmektedir (Ahunbay, 1999), Bu bağlamda, yukarıda belirtilen tüm kriterlere uygun olarak zindana verilecek işlevin yapıya uygulanabilirliği araştırılmış, yeni işlevin yapının özgün fonksiyonuna da saygılı olması gerekliliği düşünülmüsstür. $\mathrm{Bu}$ nedenle hazırlanan yeniden kullanım projesinde zindan, tarihsel olayların canlandırıldığı bir zindan müzesi ve yemekiçmek ve dinlenme amaçlı kullanılabilecek sosyal tesisi olarak tasarlanmıştır.

Yeniden kullanım projesinde, öncelikli olarak kontrollü giriş ve çıkışların sağlanması amacıyla zindan boşluğuna girişte bir kontrol kulübesi yapılmıştır. Kontrol kulübesinden geçilerek zindan iç boşluğuna girildiğinde bir açık tören ve oturma alanının planlandığı görülmektedir (Çizim 8).

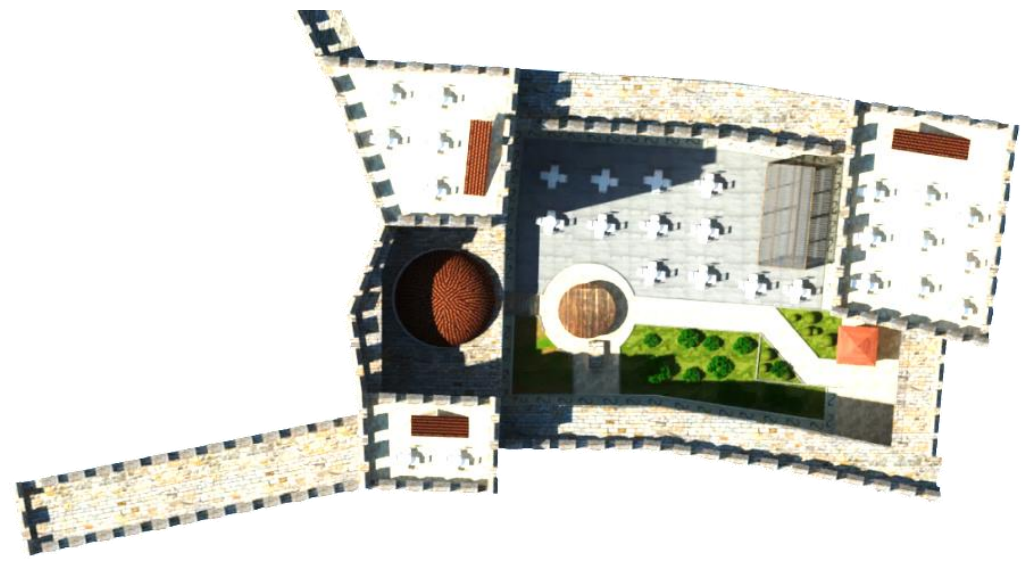

Çizim 8: Zindanın yeniden kullanımında tasarlanan iç avlu tören ve oturma alanlarının planı

(İ. Yılmaz restorasyon projesi ekinden alınmıştır.) 
Zindan iç boşluğunda planlanan açık oturma alanına yemek ve içme servisi sağlamak amacıyla, aynı zamanda yağmurlu ve soğuk havalarda da içeride oturulmasına imkân verecek şekilde, içinde büfe, oturma alanı ve wc'ler bulunan ahşap konstrüksiyon sistemde camekânlı kapalı bir ek mekân tasarlanmıştır. Tasarlanan ek mekânın sur duvarlarıyla birleştirilmediği, sur duvarı ile arasında bir boşluk bırakıldığı görülmüştür. Ayrıca iç avluda, girişten yer altı zindana doğru giden bir yürüme yolu aksı oluşturulmuş, yol aksının kenarlarında da çiçeklendirme ve bodur ağaçlardan oluşan bir peyzaj düzenlemesi yapılmıştır. Diğer yandan proje detaylarında, sur duvarı ve kulelerin alt kotlarının ve temellerinin sudan etkilenmemesini sağlamak için hem su drenajı yapılması düşünülmüş, hem de alt kısımlarda 1.00 $\mathrm{m}$. genişliğinde tretuvar düzenlemesi yapılarak, yuvarlatılmış beyaz renkli çakıl taşlar döşenmiştir. İç avluda bulunan kuyunun üzeri ise ahşap dairesel bir kapak ile kapatılmıştır. İç avludan 6 basamak ile aşağıya inilerek girilen esas zindan, danışma noktası olarak tasarlanmıştır. Buraya açılan üzeri tonozlu koridordan geçildiğinde, bu koridorla bağlantı sağlanan 8 nolu dış kulenin toprak altındaki ilk kazamatına girilmektedir. İlk kazamatta tesisat odası yerleştirilmiştir. Buradan ahşap konstrüksiyon bir merdivenle üst kazamat katına çıkılmakta, bu kazamat aynı zamanda zindan koridoruna açılmaktadır. Zindan koridorunun başında dönemine uygun olarak zindancı köşesi oluşturulmuş, zindan odaları ise müze olarak kullanılacak şekilde dizayn edilmiştir. 8 nolu dış kulenin tüm kazamat katlarıyla, 9 nolu iç kule ve 9 nolu dış kuleye ait ikişer kazamat katı ve bu kazamatların bulunduğu kulelerin üst seğirdimleri ise diğer bazı örneklerde olduğu gibi açık ve kapalı yiyecek-içecek amaçlı kafe alanları olarak düzenlenmiştir. 


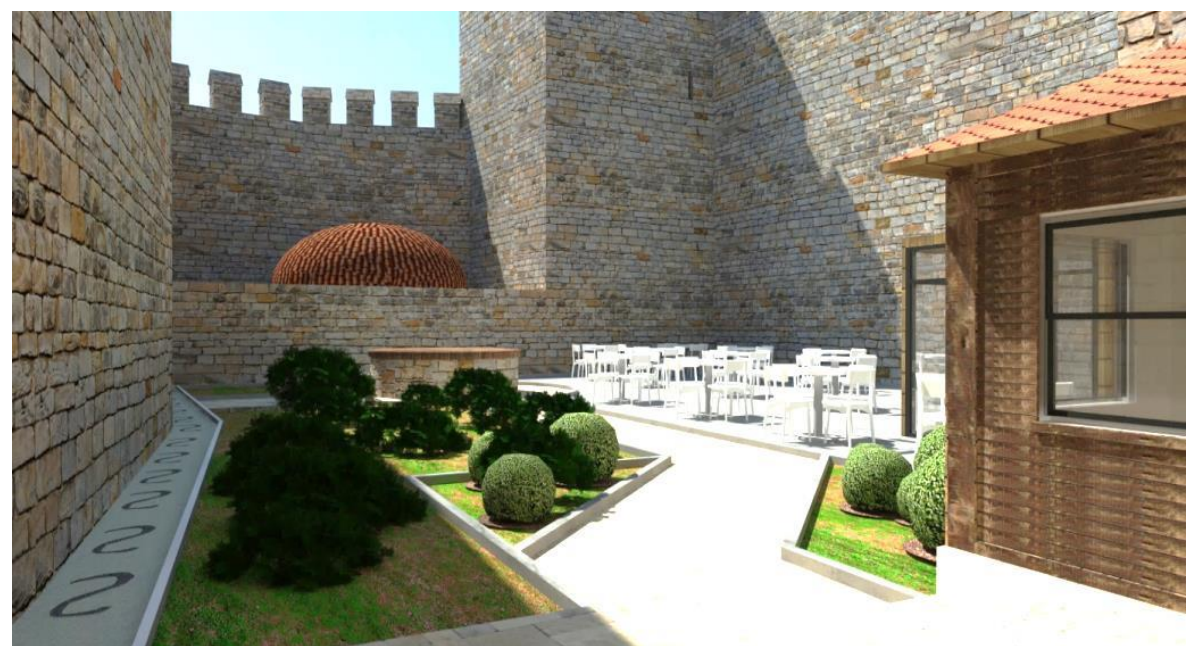

Çizim 9: Restorasyon projesinde tasarlanan zindan iç avlusunun render görünüşü

(İ. Y1lmaz restorasyon projesi ekinden alınmıştır.)

\section{SONUÇ}

Bursa şehir surları içinde yer alan ve son zamanlarda yapılan kazı çalışmalarıyla ortaya çıkartılan zindanla ilgili, Dr. Mimar İbrahim Yılmaz tarafindan bütünleşik koruma prensibine uygun olarak iki ayrı türde restorasyon projesi üretildiği görülmektedir. Bu projelerden ilki, fiziki korumaya yönelik olarak koruma ilkeleri doğrultusunda hazırlanan özgün zindan planına dönüşü sağlayan restorasyon projesidir. Bu projenin müdahale paftalarında ve restorasyon raporunda, uygulama aşamasında yapılacak müdahalelerle ilgili uyulması gereken kurallar ve ilkeler ayrıntılı biçimde açıklanmıştır. Hazırlanan ikinci proje ise yeniden kullanım projesidir. Yukarıdaki bölümlerde de anlatıldığı gibi tarihi yapıların işlevsel ömürleri fiziksel ömürleri kadar uzun olmamaktadır. İşlevsel ömrünü tamamlamış ve günümüz kullanım standartlarını sağlayamayan bir tarihi yapının fiziksel ömrünü de sürdüremeyeceği bilinen bir gerçektir. Bu nedenle, tarihi ve kültürel 
değere sahip bu tür yapıları değerlendirmenin ve gelecek nesillere özgün özellikleriyle aktarmanın en etkili yolu, yeniden işlevlendirilerek yaşamlarını sürdürmelerinin sağlanmasıdır. $\mathrm{Bu}$ bağlamda, Bursa zindanının tarihsel müze, dinlenme ve yeme-içme fonksiyonlarıyla kullanılmasını sağlayacak biçimde yeniden işlevlendirildiği bir projenin üretildiği görülmektedir. Hazırlanan yeniden kullanım projesinde yeni işlev gereksinimleri belirlenmiş, buna uygun olarak tasarlanan mekân dönüşümleriyle bu gereksinimler karşılanmaya çalışılmıştır. Ayrıca, zindan iç boşluğu tören ve açık dinlenme alanı olarak tasarlandığından, buradaki mekân dönüşümünün etkisiyle eksik kalan büfe, wc vb. servis alanı ihtiyacı, sur duvarlarına birleştirilmeden yapılarak, geriye dönülebilirlik imkanı da bulunan, ahşap malzemeden üretilecek ek bir yapıyla giderilmiştir.

Özellikleri, içeriği ve planlama anlayışı ayrıntılı biçimde anlatılan Bursa Zindanı restorasyon projesi ile özgün işlevinden uzaklaşan bu tür tarihi yapıların günümüze ayak uydurabilmeleri ve sürekliliklerinin sağlanmasında fiziki korumanın yanında, yeniden işlevlendirilerek kullanılmasının da önemi vurgulanmıştır. Bu bağlamda Bursa surlarının önemli bir parçası olan zindanın bir kültür varlığı olarak korunup ayağa kaldırılması, zindanın bir tarihsel müze ve sosyal tesis fonksiyonuyla yeniden işlevlendirilerek kullanılması kentin kültür tarihinin gelişimine, dolayısıyla turizmine önemli ölçüde katkı sağlayacaktır.

\section{KAYNAKLAR}

Ahunbay, Zeynep (1999). Tarihi Çevre Koruma ve Restorasyon. İstanbul: YEM Yayınevi.

Altınoluk, Ülkü (1998). Binalarda Yeniden Kullanım. İstanbul: YEM Yayınevi. 
Burger, Daniel (2009). "In den Turm geworfen-Gefängnisse und Folterkammern auf Burgen im Mittelalter und in der frühen Neuzeit". Forschungen zu Burgen und Schlössern Bd. 12, Deutscher Kunstverlag, Berlin ve Münih, s. 221-236.

Çelik, Deniz ve Murat Yazgan (2007). "Kentsel Peyzaj Tasarımı Kapsamında Tarihi Çevre Korumaya Yönelik Yasa ve Yönetmeliklerin İrdelenmesi”. ZKÜ Bartın Orman Fakültesi Dergisi, C. 9, S. 11, s. 1-10.

Daşcioğlu, Kemal (2006). "Osmanlı Arşivlerine Göre Sinop Hapishanesi'nin Durumu”. XV. Türk Tarih Kongresi, Ankara, s. 54-76.

Eraybat, Gamze (2011). Tarihi Konaklama Yapılarının Doğuşu, Gelişimi ve Günümüzde Çağdaş İşlevle Değerlendirilmesi: Edirne Rüstempaşa Kervansarayı Örneği . Yüksek Lisans Tezi. Edirne: Trakya Üniversitesi.

Eyüpgiller, Kemal Kutgün vd. (2008). "Korumanın Tarihi Yapıya Çağdaş Ek Boyutu: Kastamonu Çifte Hamam Örneği”. Mimarlıkta Malzeme, S. 4, s. 56-76.

Kuban, Doğan (2000). Tarihi Çevre Korumanın Mimarlık Boyutu. İstanbul: YEM Yayınlar1.

Y1lmaz, İbrahim (2014). "Bursa Sur Kapıları ve Taht-1 Kale Kapıs1 Rekonstrüksiyonu”. Uludağ Üniversitesi Fen-Edebiyat Fakültesi Sosyal Bilimler Dergisi, C. 15, S. 26, s. 87-105.

Yılmaz, İbrahim (2016a). "Osmanlı Dönemi Kubbeli Mimarlık Eserleri Restorasyon İnşaat Maliyetlerinin Yapay Zekâ Yöntemleriyle Tahmini”. International Multidisciplinary Congress of Eurasia, Odessa, s.78-91.

Y1lmaz, İbrahim (2016b). "Şehir Sur Zindanları Kapsamında Bursa Zindanının Tespiti Belgelenmesi ve Restitüsyonu”. Uludağ Üniversitesi Fen-Edebiyat Fakültesi Sosyal Bilimler Dergisi, C. 17, S. 31, s. 173194.

Uludağ Üniversitesi Fen-Edebiyat Fakültesi Sosyal Bilimler Dergisi Uludağ University Faculty of Arts and Sciences Journal of Social Sciences Cilt: 18 Sayı: 32 / Volume: 18 Issue: 32 
Uludağ Üniversitesi Fen-Edebiyat Fakültesi Sosyal Bilimler Dergisi Uludağ University Faculty of Arts and Sciences Journal of Social Sciences Cilt: 18 Sayı: 32 / Volume: 18 Issue: 32 